\title{
COBRA HEAD SIGN - AN OLD SIGN BUT NEW FINDING
}

\author{
Kalsi S.S. ', Chua N. 1, Khan S. ', Mahmood I. ${ }^{2}$
}

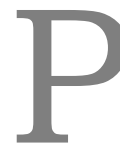

urpose. To describe the appearances of the 'cobra head sign' in a case of hydrosalpinx of the uterus. Hospital.

Material and Methods. A 35-year old woman presented with chronic abdominal Essex, UK. pain and diarrhoea to the general medicine clinic. She had symptoms on going for 2 - London North West several years and as part of her radiology work up she had several CT and MRI Healthcare NHS Trust. scans of the abdomen. During the caesarean section in 2010 she had an incidental pelvic London, UK. uterine teratoma which was also removed. After this surgery in 2010 she underwent bilateral tubal ligation for sterilisation purposes.

Results. The T2 weighted MRI of the pelvis shows high signal intensities in the uterus adjacent to the ostium of the fallopian tubes. The bilateral high signal foci are spherical and are in continuation with the dilated fallopian tubes, also demonstrating internal high T2 signal suggestive of hydrosalpinx. The rest of the endometrium, myometrium gives expected normal signal.

Conclusion. To our knowledge there are no previous cases in the literature which describe this appearance in the uterus. The cobra head sign is well documented in cases of ureterocele and the mechanism, although slightly different, remains as a result of partial obstruction. Ureteroceles are formed by a prolapse of the mucosa in the distal ureter through the ureterovesical orifice into the bladder.

Keywords: MRI, pelvis, uterus, cobra head sign, hydrosalpinx of the uterus.

Corresponding author: Mahmood I., dr_iftikhar@hotmail.com

For citation: Kalsi S.S., Chua N., Khan S., Mahmood I. Cobra head sign - an old sign but new finding. REJR. 2017; 7 (1):123-126. DOI:10.21569/2222-7415-2017-7-1-123-126.
Received:
12.08 .2016
Accepted:
17.12.2017

\section{СИМПТОМ «ГОАОВЫ КОБРЫ॥ - СТАРЫЙ ПРИЗНАК С НОВЫМИ ЗНАЧЕНИЯМИ}

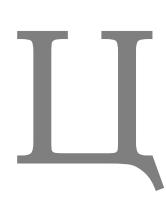

$$
\text { Калси С.С. }{ }^{1}, \text { Чуа Н. }{ }^{1}, \text { Кхан С. }{ }^{1}, \text { Maxмуд И. }{ }^{2}
$$

емь. Определить значение симптома "головы кобры" при гидросальпинксе матки.

Материамы и методы. В клинику обратилась женщина 35 лет с жалобами на длительные боли в животе и диарею. Пациентке было выполнено несколько исследований КТ и МРТ органов брюшной полости в связи с хроническими абдоминальными бомями. В 2010 году во время кесарева сечения была обнаружена и удалена тератома матки как случайная находка. После оперативного мечения в 2010 году пациентке была выполнена двусторонняя перевязка маточных труб с целью хирургической стерилизации.

Резумьтаты. На выполненных Т2-взвешенных изображениях МРТ малого таза отмечается сигнал высокой интенсивности в участках матки, прилежащих к устьям маточных труб. Участки сигнала высокой интенсивности на Т2-взвешенных изображениях сферической формы могут указывать на проявцения гидросальпинкса. В остальных отделах эндометрия и миометрия определяется сигнал нормальной интенсивности.

Выводы. Ранее в митературе не встречалось описание таких изменений в матке. Симптом "головы кобры" часто встречается при уретероцеле. Несмотря на то, что механизм возникновения может различаться, изменения обычно происходят вследствие частичной обструкции. Уретероцеле формируется вследствие пролапса слизистой оболочки дистальной части мочеточника через его устье в мочевой пузырь.

1 - Университетский госпиталь Базилтона. Эссекс, Великобритания. 2 - Иондонский северо-западный центр Национальной службы здравоохранения. Һондон, Великобритания. 
Ключевые слова: МРТ, малый таз, матка, симптом "головы кобры", гидросальпинкс матки.

Контактный автор: Mahmood I., dr_iftikhar@hotmail.com

Для иитирования: Калси С.С., Чуа Н., Кхан С., Махмуд И. Симптом «головы кобpы" - старый признак с новыми значениями. REJR. 2017; 7 (1):123-126. DOI:10.21569/2222-7415-2017-7-1-123-126.

Статья получена: $\quad 12.08 .2016 \quad$ Статья принята: 17.12 .2016

$\mathrm{P}$ uterus.

urpose of the Study.

To describe the appearances of the "cobra head" sign in a case of hydrosalpinx of the

\section{Material \& Methods.}

A 35-year old woman presented with chronic abdominal pain and diarrhoea to the general medicine clinic. She had symptoms on going for several years and as part of her radiology work up she had several CT and MRI scans of the abdomen. She previously had five pregnancies with one termination, three viable pregnancies delivered naturally, and her last viable pregnancy delivered by caesarean section. During this section in 2010, she had an incidental pelvic uterine teratoma which was also removed. After this surgery in 2010, she underwent bilateral tubal ligation for sterilisation purposes. She had no previous abdominal operations and also suffered from depression for which she only took regular sertraline. Her observations and examination were unremarkable except for mild suprapubic tenderness. Her full blood count, urea and electrolytes and liver function tests were within normal range.

Her MRI scans at the general medical clinic are shown in figure 1 and 2.

\section{Results.}

The axial and sagittal T2 weighted MRI of the pelvis shows high signal intensities in the uterus adjacent to the ostium of the fallopian tubes. The bilateral high signal foci are spherical and are in continuation with the dilated fallopian tubes, also demonstrating internal high T2 signal suggestive of hydrosalpinx. The rest of the endometrium, myometrium gives expected normal signal. No other abnormality was seen in the rest of the imaging sequences.

\section{Discussion \& Conclusions.}

Anatomically, the intramural segment of the uterus is the fallopian tubes shortest region, extending from the uterotubal junction, through the myometrium and endometrium, and opens out at the uterine ostium [1]. The intramural portions also contain about five or six blunt plicae, or folds, which encompass ciliated cells that help the ovum pass into the uterus [2]. Normally the cilia beat towards the uterus and tubal fluid is discharged from the fimbriated end into the peritoneal cavity, where it cleared, however occlusion of this end may lead to tubal dilatation [2]. Inflammatory processes may damage the tubal folds, resulting in uneven scarring and disappearance of the plicae [2]. This damage leads to markedly thin walls, and as the acute and chronic inflammatory cells are reabsorbed into the tubal wall, with the quiescence of the inflammatory process, clear fluid eventually replaces this exudate and a hydrosalpinx is formed [2].

Therefore, hydrosalpinx is essentially a fluid filled dilatation of the fallopian tube secondary to obstruction of the ampullary segement of the uterus, and is commonly caused by adhesions from previous pelvic inflammatory disease, tubal ligation, endometriosis, surgery or malignancy [3]. The blocked tube may be substantially dilated, and may be filled with pus, haemorrhage or serous fluid depending on the type and chronicity of obstruction [4]. It is important to recognise the MRI features of hydrosalpinx because they may provide clues to the nature of complex adnexal masses, in appropriate clinical settings [5].

We postulate that the patient's caesarean section for her fifth pregnancy resulted in adhesions due to endometrial trauma. In addition she had fallopian tube ligation for sterilisation (fig. 3) purposes after the caesarean section. This combination of adhesion configuration and the ligated fallopian tubes give rise to spherical collection of secretions (the spherical cobra head) and dilated fallopian tubes or hydrosalpinx (the cobra body/tail) as seen in our case (fig. 4 , fig. 5 )

If the adhesions were not present the tubal secretions from the fallopian tubes would simply empty into the uterus, as described before. Also, if the fallopian tube ligation had not taken place, secretions blocked by the downstream endometrial adhesions would most likely have collected in the peritoneal cavity. In either situation the appearance of cobra head sign seen in our patient would not have occurred. 


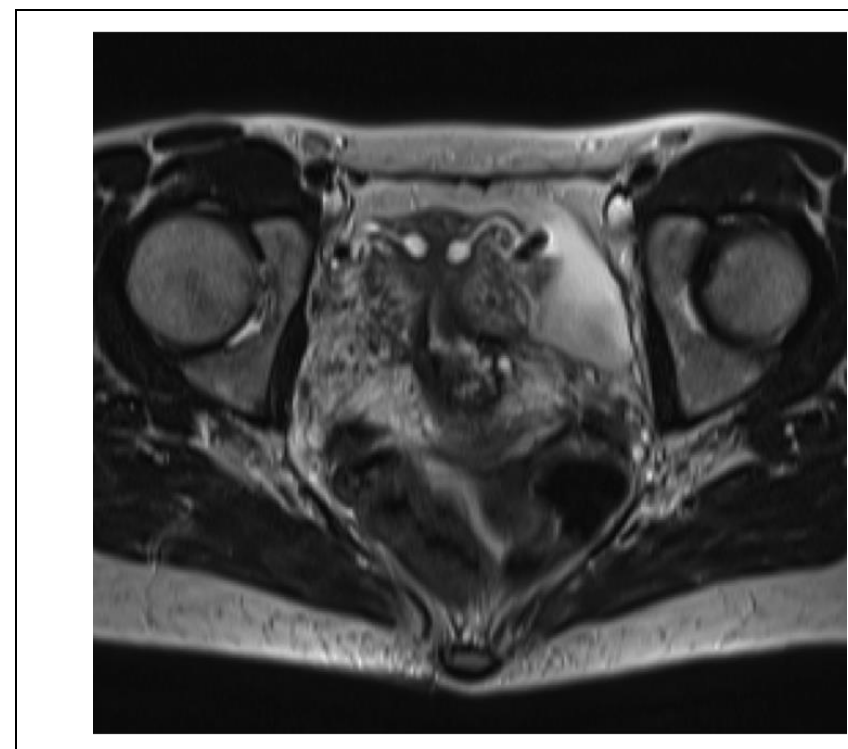

Fig. 1. MRI, T2, axial plane, pelvic region.

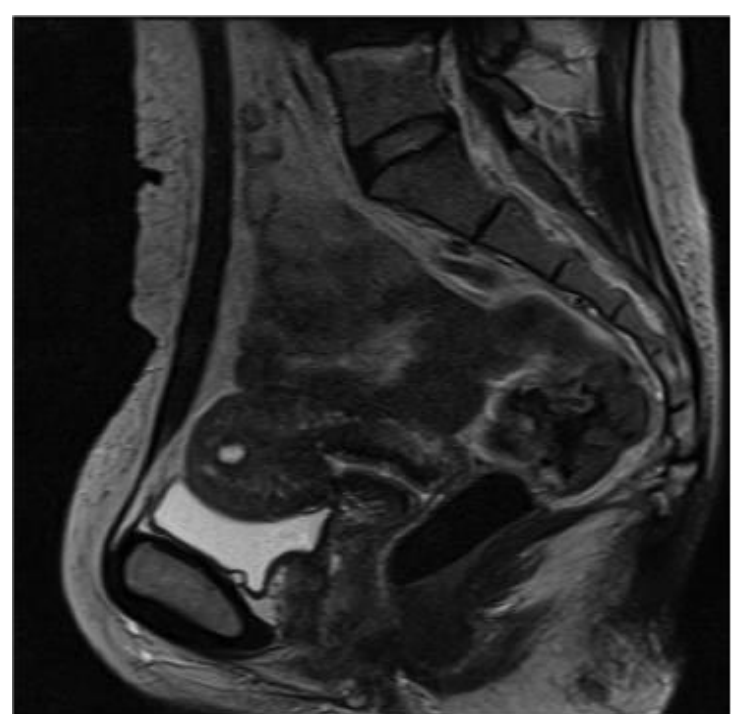

Fig. 2. MRI, T2, sagittal plane, pelvic region.

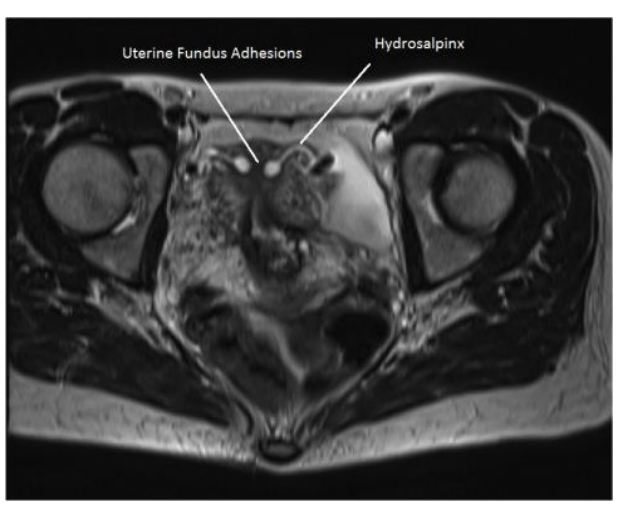

Fig. 4. MRI, T2, axial plane, pelvic region.

"Cobra head" sign (hydrosalpinx).

Hydrosalpinx, adhesions and sterilization clips.

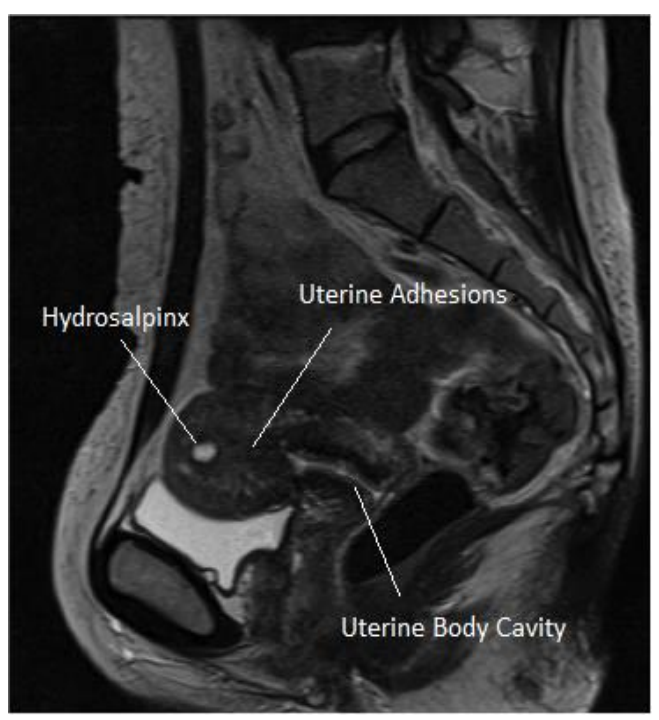

Fig. 5. MRI, T2, sagital plane, pelvic region.

Hydrosalpinx and uterine adhesions. 


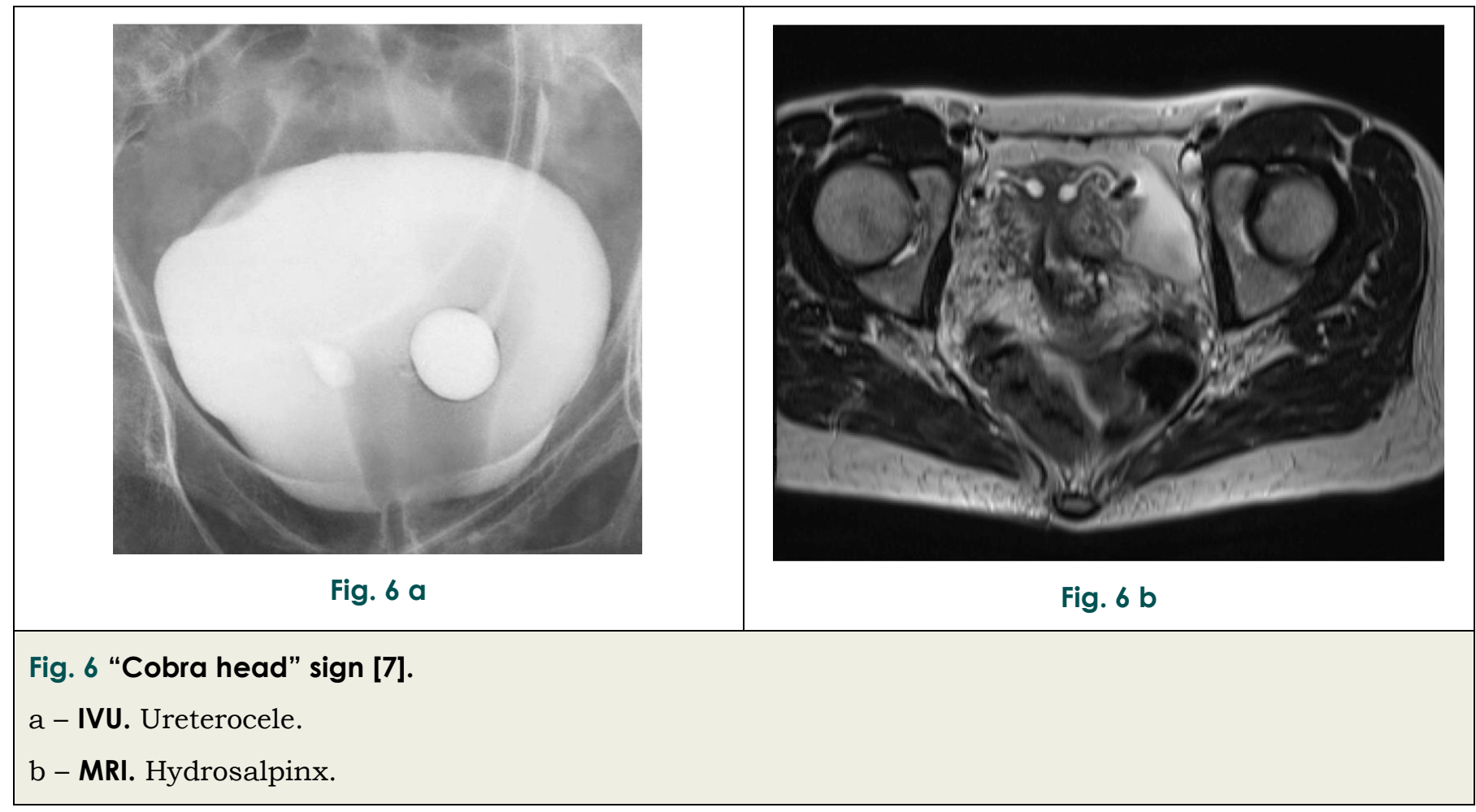

To our knowledge there are no previous cases in the literature which describe this appearance in the uterus. The cobra head sign is well documented in cases of ureterocele and the mechanism, although slightly different, remains as a result of partial obstruction. Ureteroceles are formed by a prolapse of the mucosa in the distal ureter through the ureterovesical orifice into the bladder (fig. 6, 7) [6].

A similar appearance and mechanism has been seen in intraluminal type IIIa choledochococele, a type of biliary tree cystic dilatation, again due to obstructive causes, which also resulted in a 'cobra head sign' appearance [8].

Ureteroceles are usually asymptomatic unless large. Likewise in our case, the patient's symptoms were likely attributable to a gastrointestinal cause and at six month follow up post imaging reveals she has received further work up by the gastroenterologists although she has received no formal diagnosis as yet.

\section{References:}

1. Thomas D. Histoquarterly: Fallopian Tube, 2013. Available at: https://micro2tele.com/2013/07/13/histoquarterly-fallopiantube.

2. Jarboe E. A. Fallopian Tube, 2015. Available at: http://clinicalgate.com/fallopian-tube.

3. Rezvani M., Shaaban A. M. Fallopian Tube Disease in the Non-Pregnant Patient. RadioGraphics. 2011; 31: 527-548.

4. Wheeler J. E. Pathology of fallopian tube. In: Blaustein A, ed. Blaustein's pathology of the female genital tract. 2nd ed. New York, NY, Springer-Verlag. 1984; 393-411.

5. Kim M., Rha S. E., Oh S. N., Jung S. E., Lee Y. J., Kim Y. S. et al. MRI Image findings of Hydrosalpinx: a comprehensive re-

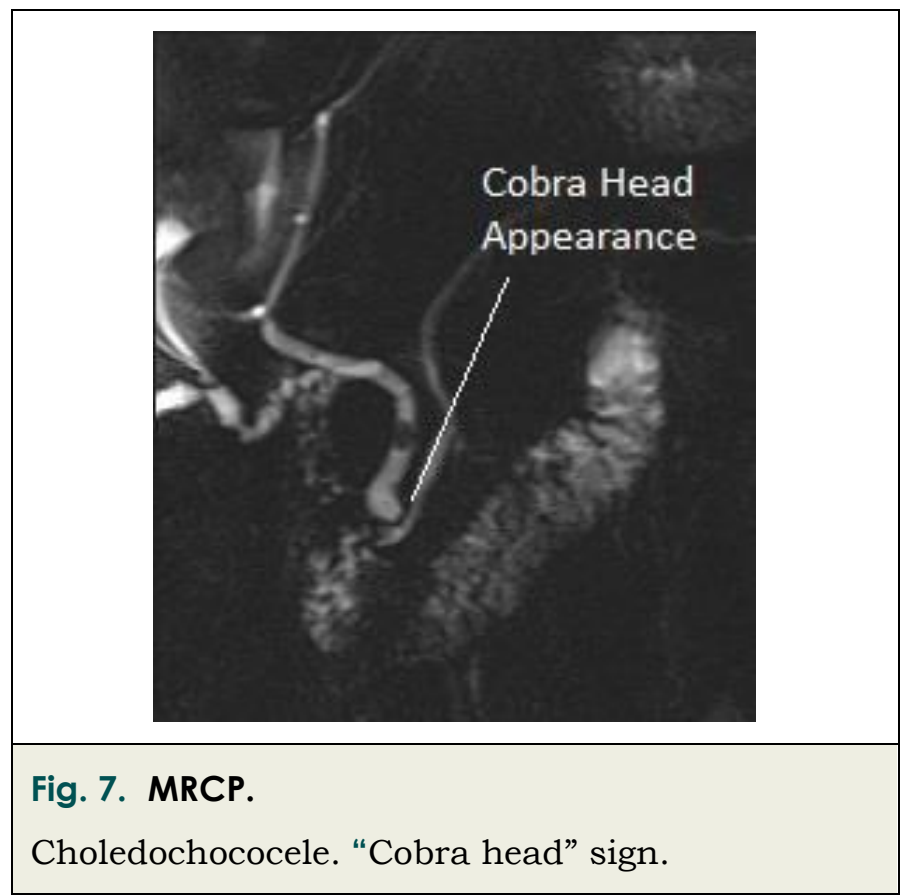

view. RadioGraphics. 2009; 29: 495-507.

6. Chavhan G. B. The Cobra Head Sign. Radiology. 2002; 225:781-782

7. Gaillard F.A. Case courtesy. Available at: radiopaedia.org, rID: 9682

8. Reibibo L., Chivot C., Fuks D., Sabbagh., Yzet T., Regimbeau $J$. Three-dimensional computed tomography analysis of the left gastric vein in a pancreatectomy. HPB (Oxford). 2012; 14 (6): 414-421. 